Talent Management Practices in the Egyptian Hotels: Talent Satisfaction Perspective

Ahmed Ramadan

Yasser Abdel-Aty
Mohamed Abo-Taleb

Tamer Mohamed Amer

Faculty of Tourism and Hotels, Sadat City University

\begin{abstract}
Today's markets are global and highly competitive. Therefore, it has become essential for corporate survival to be able to adapt and respond to change around them. In essence, talented people are a source of strength for any organization and behind its success. Organizations have to attract, develop and retain their talented employees especially those who are extraordinarily talented. The purpose of this study is to identify the effects of talent management (TM) practices on the satisfaction of employees in Egyptian hotels. To attain the study aim, one questionnaire was designed. A total of 390 questionnaire forms were distributed to the hotels. The researcher distributed 50 questionnaire forms personally by hand to talented people. For the rest (340 questionnaire forms) due to management privacy, hotels take over the responsibility of distributing questionnaires to their managers and assistant managers of the hotel departments to distribute these questionnaires to their talented people in each department. A final sample of 347 was identified as valid for statistical analysis with an $88.97 \%$ response rate. Statistical analysis SPSS version 23 was used to analyze responses to questions and test hypotheses. The study proved that there is a significant relationship between TM practices and the satisfaction of employees in hotels, and there is a positive effect of TM practices on the satisfaction of employees.
\end{abstract}

Keywords: Talent management practices; employee satisfaction; hotels.

\title{
Introduction
}

In the light of the continuous developments and the competitiveness, excellence and success are considered strategic goals for any business premises and similarly hospitality establishments (Barney and Wright, 1997; Lockwood, 2006; Lawler, 2008; Mathew). Today, with the increase of competition, the investment in human resources has become an important part of the strategies to be competitive (William et al., 2017). Bhatnagar (2007) stated that talent has become the key differentiator for human capital management, and the management of talent seems to be one of the key functions that human recourses management is playing strategically in organizations. Based on the above, Cappelli (2008) stated that the organizations 'continuous practice of excellence requires them to continually improve their capabilities to suit their clients' needs and expectations. This improvement requires highly skilled, trained, and talented human resources as well as specific practices to help them accomplish their work. This indicates the importance of TM practices in achieving high levels of strategic innovation in the short and long term. Abbasi et al., (2013) showed that talented employees are an asset for any hotel and behind the success of the hotels. Talent management is a new trend for many small and large hotels and is one of the best practices adopted by those who wish to stay in the lead and maintain their competitiveness.

Galagan (2008) produced an advanced definition of the concept, by identifying TM as a set of competencies that talented employees should adopt and perform accordingly. They should be able to benefit from those competencies and apply them in the organizational structure and finally measure the impact on future achievements and success. According to Hughes and Rog (2008, p. 
746): TM is a multi-faceted concept that has been supported by HR practitioners, fueled by the war for talent and built on the foundations of HRM. Xin and Preece (2008) claimed that TM is not different from HRM, as both attract the right people for the right jobs at the right time. Moreover, TM uses the same tools as HRM. However, the focus of attention in TM is on a small group of talented employees, who belong to the talent pool. Huang and Tansley (2012) defined TM as an HRM innovation, which possesses unique characteristics and a concentration on top high performers in the company, on their development, promotion, and retention. Accordingly focusing on high-class performers can bring many tensions because this approach can be regarded as politically incorrect, acting against the principle of equal opportunity.

\section{Research Hypotheses}

$\mathrm{H}_{1}$ : There is no relationship between TM practices and employee satisfaction.

$\mathrm{H}_{2}$ : There is an effect of TM practices on employee satisfaction.

\section{Literature Review}

The hospitality industry is customer-oriented, and it depends heavily on labor to meet customer satisfaction. Thus, there is a majority opinion that the quality of employee performance has the most impact on customer satisfaction (Lee et al., 2015; He et al., 2011). Having the right talent or quality workers is one of the key elements for business success (He et al., 2011). This also appears to have a significant impact on customer repurchase intentions and customer loyalty (Lee, et al., 2015). In the hospitality industry, customer experience of services is highly dependent upon personal interaction between employees and customers (Mullins 1998). As facilities and amenities are duplicated across the organization to organization, the positive attitude and behavior of employees can contribute to a favorable impression about the hotel (Lovelock et al., 2005).

In the present competitive and increasingly complex global economy, job satisfaction represents one of the most challenging areas faced by today's service-based companies' managers when it concerns managing their employees. A positive attitude towards the job indicates job satisfaction. A study on employee engagement and business success showed that employees who were extremely satisfied at work were four times more likely than the employees who are dissatisfied (Lockwood et al., 2006). Individuals choose organizations that complement their personality and organizations choose individuals who have personalities that complement the organization. When this occurs, there is a fit that represents the degree of job satisfaction (Judge et al., 2000).

Organizational effectiveness refers to the organization's success in achieving its pre-set objectives via formulating its current resources, which could be reflected in the employee's degree of satisfaction with their current job positions, and the degree of their involvement with the organizations. Organizational effectiveness is activated into two dimensions; the first is the extent of an employee's satisfaction towards his or her job. Job satisfaction can be reflected in having a good connection and communication with his or her supervisor, a good income, and the ability to perform the job's tasks effectively. The second dimension is related to the extent of involvement with the organization that the employee enjoys; on an emotional, continuance, and normative basis (Allen and Meyer, 1990).

Job satisfaction refers to the degree to which the employee is satisfied with his/ her job nature, and to what extent he/she is compatible with the provided awards such as; the amount of payment, insurance coverage, travel, and scholarships (Allen and Meyer, 1990). 
In the business process, outsourcing industry staff satisfaction is always in proportion with money received and it shows quickly compared to other industries. This is one of the major reasons why attrition levels are high in the BPO's (Feldman, 2000). A study carried by Mwangi (2009) revealed that poor reward schemes would have contributed to the loss of talent.

Evidence from a study done by Griffeth et al., (2000) revealed that employee turnover is usually resulting from factors causing job dissatisfaction such as job content, poor working conditions, and low pay. According to Suleiman et al., (2013), employees have the intention to leave their current organization when they face dissatisfaction in their job. MacIntosh and Doherty (2010) and AlBattat and Mat Som (2013) stated that job dissatisfaction is the main reason forcing employees to depart from their current job and look for better job opportunities. Presser and Almeida (2004) stated that shift work is significantly related to child-related problems and greater marital disagreements. Shift work is common in hotel work puts challenges for hotel employees trying to negotiate the work-family interface. Cleveland et al. (2007) claimed that shift work and the number of working hours, as a work demand and the nature of the job in the hospitality industry, could have a significant effect on the psychological, physical, and emotional welfare of hospitality employees. Kucukusta et al. (2014) stated that Long and unpredictable working hours are reasons for employees' job dissatisfaction.

$\mathrm{TM}$ is a recent, practitioner-generated term covering a range of long-term practices that aim at getting the right person in the right job at the right time. These include workforce planning, succession planning, employee development, and career management (Morton, 2005). Building relationships with people, identifying talent and Capabilities, planning learning and development activities, and getting most of the talent that the organization is having (Armstrong, 2010).

Talent wants a big job, where they have responsibility for several functional responsibilities, and where they can make decisions on their own (Fishman, 1998). Armstrong (2006) stated that talented individuals are allowed to develop in their current positions and can transfer to a new position through training and development. Developing employees to help them grow with the organization and training them for the expertise needed to contribute to business success also builds loyalty and improves employee engagement (Iles, 2008). A study on employee engagement and business success showed that employees who were extremely satisfied at work were four times more likely than the employees who are dissatisfied (Lockwood et al., 2006).

\section{Methodology}

This research presents the quantitative approach used to facilitate a deductive approach to exploring the TM practices in Egyptian hotels, and the effect of these practices on the employees' satisfaction. The purpose of this research is to offer the logical basis for the methodological choices made during this research and to explain how the data were collected and analyzed. A descriptive and analytical approach was followed in this study, which described the phenomenon. In general, Cairo has been chosen as an area of investigation since it is the most dominant economic, social and political city in Egypt.

The talented people were identified by giving a list of talented specifications to the department managers in each hotel and asking them to distribute the questionnaire to the workers who meet these attributes (These attributes are shown in appendix C). Therefore, the researcher selected a group of talented employees because they were directly affected by the issues of satisfaction, and therefore they will give useful information for the study. The technique of convenient sampling 
was used to divide the population into different classes, which included: talented, whether employees at low or high levels (Eusebius, 2016).

\section{Measurement and Instrument}

Due to its effectiveness in gathering empirical data from large samples, the questionnaire is the frequently used method of data collection. It is used to measure knowledge, attitudes, emotion, awareness, intention, or behavior. These considerations make using a questionnaire the most effective data collection tool for this study. The sections of the questionnaire were derived from published literature. To obtain a high response rate, it was necessary to make questions clear, answerable, and neutral. The expression and language used in this questionnaire were kept as simple as possible to communicate with the hotel employees. The questionnaire form being used in the study is composed of three parts to facilitate the data analysis process. These three sections were shown in table (1) as follows: characteristics of the hotel, TM practices, and job satisfaction.

Table (1): Sections of the questionnaire

\begin{tabular}{|l|l|c|}
\hline \multicolumn{1}{|c|}{ Sections } & \multicolumn{1}{|c|}{ Scales } & Adapted from \\
\hline Section 1 & Characteristics of the hotel & Nasr, 2017 \\
\hline Section 2 & TM practices & Khairy, 2015 \\
\hline Section 3 & Job satisfaction & Bettye, 2017 \\
\hline
\end{tabular}

\section{Data Collection}

This study focused on investigating how the concept of TM practices is being applied within fivestar hotels. After collecting the contact information of the investigated hotels, telephone calls were made to the managers of the human resource departments to get their permission to visit their hotels and distribute the questionnaire forms to the talented employees. All the questionnaire forms were distributed in March 2021. These forms were retrieved after one month from distribution, and that was in April 2021. Telephone contacts have been made with the human resources managers in each hotel and following up with them weekly, who in turn followed up filling out the forms with the talented people in each department with the department managers in the hotel, and they were very cooperative after that these forms were retrieved in April 2021 from all participating hotels.

\section{Data Analysis}

A five-point Likert-type scale was used to measure the respondent's answers. Different statistical tests were used to address the research questions for the study. The statistical package for social sciences (SPSS) v.23 was used to analyze the data collected. Descriptive statistics were employed to identify the talent management practices as well as employee satisfaction in the investigated hotels. In addition, the Spearman correlation coefficient was used to find the relationships among variables. Moreover, the hierarchal multiple regression was used to examine the impact of talent management practices on employee satisfaction.

\section{Validity and reliability of the study instrument}

The Cronbach alpha reliability was computed, and the tests showed that the reliability coefficients for all items were above 0.60 . For this study, Cronbach alpha for all survey constructs is presented in table (2). 
Table (2): Cronbach alpha for study instruments

\begin{tabular}{|c|l|c|c|}
\hline Serial & \multicolumn{1}{|c|}{ Instrument } & $\begin{array}{c}\text { Number } \\
\text { of items }\end{array}$ & $\begin{array}{c}\text { Cronbach alpha } \\
\text { coefficient }\end{array}$ \\
\hline 1 & TM Practices & 38 & 0.985 \\
\hline 2 & Employees job satisfaction & 9 & 0.995 \\
\hline
\end{tabular}

Concerning validity, the questionnaire was initially pre-tested for its validity with three professors at the hotel studies department at the faculty of tourism and hotels in the University of Sadat City to get feedback regarding the clarity of the instructions and accuracy of the questions in the instrument. Comments and suggestions obtained from them were used for rewording the instructions and layouts of the questionnaire.

\section{Results}

\section{Demographic Profile of Respondents}

The questionnaires used for this study included three items concerning the respondents' demographic characteristics and other work-related information. The respondents were asked about their gender, age, and educational level. This information was useful in understanding the background of the respondents. Results are presented in table (3).

Table (3): Demographics Respondents

\begin{tabular}{|l|l|c|c|}
\hline \multirow{2}{*}{ Demographic Respondents } & \multicolumn{1}{|c|}{ Classes } & Freq. & \% \\
\hline \multirow{4}{*}{ Gender } & Male & 297 & 85.5 \\
\cline { 2 - 4 } & Female & 50 & 14.4 \\
\cline { 2 - 4 } & Total & $\mathbf{3 4 7}$ & $\mathbf{1 0 0}$ \\
\hline \multirow{4}{*}{ Age } & Less than 30 years & 36 & 10.4 \\
\cline { 2 - 4 } & From 30 to less than 40 years & 84 & 24.2 \\
\cline { 2 - 4 } & From 40 to less than 50 years & 173 & 49.9 \\
\cline { 2 - 4 } & 50 years and more & 54 & 15.5 \\
\cline { 2 - 4 } & Total & $\mathbf{3 4 7}$ & $\mathbf{1 0 0}$ \\
\hline \multirow{3}{*}{ Educational Level } & High school. & 7 & 2 \\
\cline { 2 - 4 } & Bachelors. & 17 & 89.9 \\
\cline { 2 - 4 } & Masters. & $\mathbf{3 4 7}$ & $\mathbf{1 0 0}$ \\
\cline { 2 - 4 } & Ph.D. & & 3.1 \\
\cline { 2 - 4 } & Total & 11 & $\mathbf{1 0}$ \\
\hline
\end{tabular}

The data in the table (8), indicate that out of the 347 respondents, $297(85.5 \%)$ were males and 50 $(14.4 \%)$ were females. Only $36(10.4 \%)$ of the respondents were less than 30 years old, 84 $(24.2 \%)$ were from 30 years and less than 40 years old group, 54(15.5\%)of the respondents have 50 years old and more, and the rest of the sample(49.9.7\%) were from 40 years and less than 50 years old. 
The data also indicate that only $11(3.1 \%)$ of the respondents possess a doctorate, $17(5 \%)$ of the respondents possess a master's degree, and $312(89.9 \%)$ of the respondents have a bachelor's degree.

\section{Job Satisfaction}

Table 4 shows the descriptive analysis regarding the variable of job satisfaction. The results showed that the total mean of employee job satisfaction was 4.38. In addition, it could be noticed that all nine items of employee job satisfaction had average scores above four. These results indicated the importance of good management practice, which in turn leads to employee satisfaction and loyalty to the hotel.

Table (4): The descriptive analysis regarding the variable of job satisfaction

\begin{tabular}{|l|c|c|c|c|c|c|c|c|c|c|c|}
\hline \multirow{2}{*}{ Job Satisfaction } & \multicolumn{2}{|c|}{ SD } & \multicolumn{2}{|c|}{ D } & \multicolumn{2}{|c|}{ N } & \multicolumn{3}{|c|}{ A } & \multicolumn{3}{|c|}{ SA } & Mean \\
\cline { 2 - 12 } & F & \% & F & \% & F & \% & F & \% & F & \% & 4.38 \\
\hline $\begin{array}{l}\text { I feel a sense of pride } \\
\text { in doing my job. }\end{array}$ & 10 & 2.9 & 11 & 3.1 & 19 & 5.5 & 97 & 28.0 & 210 & 60.5 & 4.40 \\
\hline $\begin{array}{l}\text { I feel satisfied with } \\
\text { my chances for salary } \\
\text { increases. }\end{array}$ & 9 & 2.5 & 12 & 3.5 & 20 & 5.8 & 102 & 29.3 & 204 & 58.9 & 4.38 \\
\hline $\begin{array}{l}\text { The benefits package } \\
\text { we have is equitable. }\end{array}$ & 7 & 2.1 & 9 & 2.5 & 19 & 5.6 & 105 & 30.3 & 207 & 59.5 & 4.43 \\
\hline $\begin{array}{l}\text { Communications } \\
\text { seem good within this } \\
\text { organization. }\end{array}$ & 10 & 3.0 & 14 & 4.0 & 18 & 5.3 & 103 & 29.6 & 202 & 58.1 & 4.36 \\
\hline $\begin{array}{l}\text { I am satisfied with my } \\
\text { chances } \\
\text { promotion. }\end{array}$ & 5 & 1.5 & 9 & 2.5 & 14 & 4.1 & 106 & 30.4 & 213 & 61.5 & 4.48 \\
\hline My job is enjoyable. & 12 & 3.6 & 20 & 5.7 & 23 & 6.7 & 98 & 28.1 & 194 & 55.9 & 4.27 \\
\hline $\begin{array}{l}\text { When I do good job, } \\
\text { I receive the } \\
\text { recognition that I } \\
\text { should receive. }\end{array}$ & 5 & 1.4 & 11 & 3.2 & 16 & 4.5 & 107 & 30.8 & 208 & 60.1 & 4.45 \\
\hline $\begin{array}{l}\text { I like the people I } \\
\text { work with. }\end{array}$ & 7 & 2.1 & 9 & 2.5 & 20 & 5.6 & 106 & 30.3 & 205 & 59.5 & 4.42 \\
\hline $\begin{array}{l}\text { I like doing the things } \\
\text { I do at work. }\end{array}$ & 12 & 3.6 & 20 & 5.7 & 23 & 6.7 & 98 & 28.1 & 194 & 55.9 & 4.27 \\
\hline
\end{tabular}

* SD= Strongly Disagree, $\mathrm{D}=$ Disagree, $\mathrm{N}=$ Neutral, $\mathrm{A}=$ Agree, $\mathrm{SA}=$ Strongly Agree

\section{Results of Hypotheses Test}

\section{Relationship between TM practices and job satisfaction}

As shown in table (5), there is a highly significant correlation at (0.01) level between TM practices and job satisfaction. The Spearman's correlation is positive and strong, the ratio bigger than 0.9. The results also indicated that TM practices variable has a strong relationship with the job satisfaction variable. As a result, the null hypothesis that there is no relationship between TM 
practices and job satisfaction was rejected. The existence of a relationship between TM practices and job satisfaction was supported.

Table (5): The correlation between TM practices and job satisfaction

\begin{tabular}{|l|l|l|c|c|}
\hline \multirow{4}{*}{ Spearman } & Variables & & TM Practices & Job Satisfaction \\
\hline \multirow{4}{*}{ TM Practices } & Correlation & $.916^{* *}$ & 1.000 \\
\cline { 3 - 5 } & & Sig. & .000 & \\
\cline { 3 - 5 } & $\mathrm{N}$ & 347 & 347 \\
\cline { 2 - 5 } & \multirow{3}{*}{ Job Satisfaction } & Correlation & 1.000 & $.916^{* *}$ \\
\cline { 3 - 5 } & Sig. & & .000 \\
\cline { 3 - 5 } & $\mathrm{N}$ & 347 & 347 \\
\hline \multirow{2}{*}{$* *$ Correlation is significant at the 0.01 level (2-tailed). } \\
\hline
\end{tabular}

\section{The effect of TM practices on job satisfaction for talented people}

Multiple regression analysis was conducted to examine the influence of TM practices on job satisfaction of talented employees among the hotels in Egypt. The findings are indicated in subsequent sections: It can be noticed from the results in a table (6) that there is a strong positive correlation between TM practices and job satisfaction $(\mathrm{R}=0.975)$. Furthermore, it is noticed that the value of adjusted R2 is equal to the value of $\mathrm{R} 2$. This means that this model had the whole population participating in the study, and the highest variance in outcome was at 0.000 .

Table (6): The effect of TM practices on job satisfaction for talented people

\begin{tabular}{|l|c|c|c|c|c|c|}
\hline \multirow{2}{*}{ Variables } & \multicolumn{2}{|c|}{ ANOVA } & Coefficients (a) & \multicolumn{3}{|c|}{ Model summary } \\
\cline { 2 - 7 } & $\mathrm{F}$ & Sig. & $\mathrm{T}$ & $\mathrm{R}$ & $\mathrm{R}^{2}$ & Adjusted R \\
\cline { 2 - 7 } & 6680.91 & $.000^{\mathrm{a}}$ & & .975 & .951 & .951 \\
\hline TM Practices & & & 81.737 & & & \\
\hline Job satisfaction & & & 7.468 & & & \\
\hline
\end{tabular}

Also, table (6) shows the probability of F-value and that it is significant at 0.05 , which indicates that TM practices have a significant effect on job satisfaction, the effectiveness at $(\alpha \leq 0.05)$. Therefore, the null main hypothesis is rejected, and the alternative is accepted with the statistically significant effect at the level $(\alpha \leq 0.05)$ by TM practices on job satisfaction. Referring to the first sub-hypothesis $\mathrm{H} 1$; the sig value is (0.000), and it is significant at $(\alpha \leq 0.05)$. This indicates that the variable of TM practices has a significant effect on job satisfaction at $(\alpha \leq 0.05)$. Therefore, the null hypothesis is rejected, and the alternative is accepted with a statistically significant effect at $(\alpha$ $\leq 0.05)$.

\section{Regression model specification and estimation to establish the influence of TM practices on job satisfaction}

Table (7) indicates the model summary. From the findings, $\mathrm{R}$ was $0.976, \mathrm{R}^{2}$ was 0.952 , and adjusted $\mathrm{R}^{2}$ was 0.952 . An $\mathrm{R}$ square of 0.952 implies that $95.2 \%$ of changes in job satisfaction of talented employees among the hotels in Egypt are explained by the independent variable of the study. However, other factors influence the job satisfaction of talented employees among the 
hotels in Egypt that are not included in the model which account for $4.8 \%$. An $\mathrm{R}$ of 0.976 on the other hand signifies a strong positive correlation between the variables of the study.

Table (7): Model Summary

\begin{tabular}{|c|c|c|c|c|}
\hline Model & $\mathbf{R}$ & $\mathbf{R}^{\mathbf{2}}$ & Adjusted $\mathbf{R}^{\mathbf{2}}$ & $\begin{array}{c}\text { Std. error of } \\
\text { the Estimate }\end{array}$ \\
\hline 1 & $.976 \mathrm{a}$ & .952 & .952 & .19678 \\
\hline
\end{tabular}

As shown in table (8), the value of F calculated is 2272.62 while $F$ critical is 4.465 . Since the value of $\mathrm{F}$ calculated is greater than $\mathrm{F}$ critical, the overall regression model was significant and therefore a reliable indicator of the study findings. In terms of $p$ values, the study indicated .000 which is less than 0.05 and therefore statistically significant.

Table (8): ANOVA

\begin{tabular}{|l|c|c|c|c|c|}
\hline \multicolumn{7}{|c|}{ ANOVA } \\
\hline Model & Sum of Squares & $d f$ & Mean Square & F & Sig. \\
\hline Regression & 264.005 & 3 & 88.002 & 2272.623 & $.000 \mathrm{a}$ \\
\hline Residual & 13.282 & 343 & .039 & & \\
\hline Total & 277.287 & 346 & & & \\
\hline
\end{tabular}

From the results in table (9) the resultant regression equation becomes as follows: Y (Regression Coefficient $)=-0.232($ TM Practices $)+0.644($ Job Satisfaction $)$.

Table (9): Regression Coefficients

\begin{tabular}{|l|c|c|c|c|c|}
\hline \multirow{3}{*}{ Model } & \multicolumn{2}{|c|}{$\begin{array}{c}\text { Unstandardized } \\
\text { Coefficients }\end{array}$} & $\begin{array}{c}\text { Standardized } \\
\text { Coefficients }\end{array}$ & \multirow{2}{*}{$\mathrm{t}$} & \multirow{2}{*}{ Sig. } \\
\cline { 2 - 5 } & $\mathrm{B}$ & Std. Error & Beta & & \\
\hline Constant & -0.232 & 0.063 & & 3.683 & 0.000 \\
\hline Job Satisfaction & 0.644 & 0.108 & 0.655 & 5.970 & 0.000 \\
\hline
\end{tabular}

\section{Discussion}

Interest in studying the TM concept, in terms of its definition, importance, and literature review, has increased, especially for academics and researchers. TM focuses on positioning the right person in the right place, encouraging employees to develop their qualifications and talent which, in return, serves to enrich and sustain the success of the organization (Chambers et al., 1998). Prior research undertaken to study TM has mainly focused on the conceptualization of talent and talent management, as well as TM practices. As a result, the purpose of the present study was to investigate the impact of TM practices (i.e., attraction, retention, engagement, development, and work-life balance) on employee satisfaction. The talented people were identified by giving a list of 
talented specifications to the department managers in each hotel and asking them to distribute the questionnaire to the workers who meet these specifications. Therefore, the researcher selected a group of talented employees because they were directly affected by the issues of job satisfaction, and therefore they will give useful information for the study. The technique of convenient sampling was used to divide the population into different classes, which included: Talented, whether employees at low or high levels. These talented people were grouped according to the functions of either the front or back offices of the hotel. They were chosen by the researcher on the basis that they were directly affected by issues to examine the relationships between the independent and dependent variables.

The findings of our study showed that there was a significant impact of TM practices (independent variable) on employee satisfaction (dependent). Regarding the effect of TM practices on talent satisfaction, the result of this study revealed that there is a significant relationship between TM practices and talent satisfaction. The results come to support the findings of Allen and Meyer (1990), who hypothesized that job satisfaction refers to the degree to which the employee is satisfied with his/ her job nature, and to what extent he/she is compatible with the provided awards such as; the amount of payment, insurance coverage, travel, scholarships. Besides, these results support the findings of Smithers and Walkers (2000), who argued that talented employees want the self-esteem and appreciation of others and this has a positive impact on productivity levels and employee motivation.

The results of this research have some managerial implications, which can help managers achieve their organizational goals effectively. It is clear from the results that management pays attention to attracting and retaining talent in the industry, hence the need to implement TM practices to improve the satisfaction of talented people and enable them to obtain a competitive advantage in the market where they work. TM should be considered as more than just a theoretical concept, managers must convert their minds range from discussing TM practices informally to formally implementing them in all matters of A and B level employees, to get A level talents on the line of leaders, while B level from the employees must improve their skills at work. Based on the above results and discussion of the final hypotheses, it is clear from the hypotheses of the study that there is a relationship and a direct effect of TM practices on the job satisfaction of talented employees in the five-star hotels in Egypt, it was shown on the regression model that, $\mathrm{R}$ was 0.976 , R square was 0.952 , and adjusted $R$ squared was 0.952 . An $R$ square of 0.952 implies that $95.2 \%$ of changes in job satisfaction of talented employees among the hotels in Egypt are explained by the independent variable of the study. There are however other factors that influence job satisfaction of talented employees among the hotels in Egypt that are not included in the model which account for $4.8 \%$. An $\mathrm{R}$ of 0.976 on the other hand signifies a strong positive correlation between the variables of the study.

\section{Results of testing study hypotheses}

Table (10): Results of Testing Study Hypotheses

\begin{tabular}{|l|c|}
\hline \multicolumn{1}{|c|}{ Hypotheses } & Testing Result \\
\hline $\begin{array}{l}\text { H1: There is no relationship between TM practices and } \\
\text { employee satisfaction. }\end{array}$ & Rejected \\
\hline $\begin{array}{l}\text { H2: There is an effect between TM practices and employee } \\
\text { satisfaction. }\end{array}$ & Supported \\
\hline
\end{tabular}




\section{Conclusion}

The goal of this study was to explore the different current practices of TM in hotels, and the impact of these practices on the job satisfaction of talented employees. To identify the relationship between TM practices and employee satisfaction, the study collected the required data by distributing well-administered questionnaire forms to a sample of 347 respondents representing 39 five-star hotels in great Cairo. The study also revealed that there is an effect of TM practices (TMP) on employee satisfaction, with a response rate of 81.73 . Hence, it is clear that good TM practices have a strong and direct impact on the employee satisfaction of talented workers where it makes A-level employees on the line of leaders, while B level from the employees needs to improve their skills at work.

\section{Recommendations}

Based on the findings of this study, several recommendations can be suggested. Hotels should care and support talent management, and develop an action plan that includes all the practices that take place with the talented employees from recruitment, training, development, participation, and retention, and ensure that this plan is implemented with all its practices and at all levels in the hotel. Talented employees should feel properly valued to stay in the hotel longer, and the hotel should prioritize social recognition and financial rewards with meaningful pay. The hotel must appreciate talents in the work, motivate them to raise their job satisfaction. The hotel should prepare well job descriptions for each job and make regular updates on all jobs within the hotel and training employees on these updates.

\section{References}

Abbasi, M., Sohail, M., Cheema, F., \& Syed, N. (2013) Talent Management as Success Factor for Organizational Performance: A Case of Pharmaceutical Industry in Pakistan. Journal of Management and Social Sciences. Vol. 9, No. 1.

AlBattat, A. R. S., \& Som, A. P. M. (2013). Employee dissatisfaction and turnover crises in the Malaysian hospitality industry. International Journal of Business and Management, 8(5), 62.

Allen, N., \& Meyer, J. (1990). The measurement and antecedents of affective, continuance, and normative commitment to the organization. The Journal of Occupational Psychology, 63, 118.

Al-Jarradi, K. (2011). An Investigation into the Effectiveness of the Reward System in the Government Sector in the Sultanate of Oman and the Potential for Introducing a Total Reward Strategy. Ph.D. thesis, University of Manchester.

Armstrong, M. (2006). A Handbook of Human Resource Management Practices, 10th edition. London: Kogan Page.

Armstrong, M. (2010), Armstrong's essential, human resource management, 1st Edition, London, PP.205-206.

Baum, T., (2008). Implications of hospitality and tourism labor markets for talent management strategies. International Journal of Contemporary Hospitality Management, 20(7), 721-729.

Barney, J. B., \& Wright, P. M. (1997). On Becoming a Strategic Partner: The Role of Human Resources in Gaining Competitive Advantage. Cornell University ILR School. 
Bettye, H. (2017). Employee Turnover Intentions in the Hospitality Industry. A thesis for the degree of Ph.D. Walden University.

Bhatnagar J (2007). Talent management strategy of employee engagement in Indian ITES employees: the key to retention. Employee Relations, 29(6),640-663. doi:10.1108/01425450710826122.

Cappelli, P. (2008). Talent on demand: managing talent in an age of uncertainty. Boston: Harvard Business Press.

Chambers, E., Foulon, M., Handfield-Jones, H., Hankin, S., \&Michaels III, E., (1998). The war for talent. The McKinsey Quarterly 3, 44-57.

Cleveland, J. N., O'Neill, J. W., Himelright, J. L., Harrison, M. M., Crouter, A. C., \& Drago, R. (2007). Work and family issues in the hospitality industry: Perspectives of entrants, managers, and spouses. Journal of Hospitality \& Tourism Research,31(3), 275-298. doi:10.1177/1096348007299919

Collings, D.G. and Mellahi, K. (2009). "Strategic talent management: a review and research agenda”, Human Resource Management Review, Vol. 19, No. 4, pp. 304-13.

Eusebius, M. (2016). State of University Education in Kenya. Researchgate.

Feldman, D. (2000). The Dilbert syndrome: How employee cynicism about ineffective management is changing the nature of careers in organizations. American Behavioral Scientist, (43): 1286-1301.

Fishman, C. (1998). The war for talent. FastCompany, Issue 16 (July),104. Financial Times (2006). The view of the future from Davos. January.

Galagan, P., (2008). Talent Management. What is it, who owns it, and why should you care? American Society of Trading and Development, 5, 41-44.

Griffeth, R. W., Hom, P. W., \& Gaertner, S. (2000). A meta-analysis of antecedents and correlates of employee turnover: update, moderator tests, and research implications for the next millennium. Journal of Management, 26, 463-488. doi:10.1016/S0149-2063(00)00043-X

He, Y., Li, W., \& Keung Lai, K. (2011). Service climate, employee commitment, and customer satisfaction. International Journal of Contemporary Hospitality Management, 23(5), 592607. doi:10.1108/09596111111143359.

Horváthová, P. (2011). The Application of Talent Management at Human Resource Management in Organization 2011. $3^{\text {rd }}$ International Conference on Information and Financial Engineering, IPEDR vol.12.

Hong, E. N. C., Hao, L. Z., Kumar, R., Ramendran, C., \& Kadiresan, V. (2012). An Effectiveness of Human Resource Management Practices on Employee Retention in Institute of Higher Learning: A Regression Analysis. International Journal of Business Research and Management (IJBRM), 3(2), 60-79.

Huang, J., \& Tansley, C., (2012). Sneaking through the minefield of talent management: the notion of rhetorical obfuscation. The International Journal of Human Resource Management, 1-19.

Hugles, J. C., Rog, E., (2008). Talent Management: A strategy for improving employee recruitment, retention, and engagement within hospitality organizations. International Journal of Contemporary Hospitality Management, 20(7), 743-757.

Iles, P. (2008). Talent balancing: Staffing your company for long-term success. Human Resource Development International, http://dx.doi.org/10.1080/1367886080193300

11(2),215218.

doi: 
Judge, T. A., Bono, J. E., \& Locke, E. A. (2000). Personality and job satisfaction: The mediating role of job characteristics. Journal of Applied Psychology, 85, 237-249.

Khairy, H. (2015). The Relationship between organizational politics and human resource management practices in the five-star hotels. A thesis for the degree of Ph.D. University of Sadat City

Kucukusta, D., Denizci Guillet, B., \& Lau, S. (2014). How Do Five- and Six-Day Work Schedules Influence the Perceptions of Hospitality Employees in Hong Kong? Asia Pacific Journal of Tourism Research, 19(2), 123-143. doi:10.1080/10941665.2012.734523

Kusluvan, S., Kusluvan, Z., Llhan, I., \&Buyruk, L. (2010). The human dimension: a review of Human Resources Management issues in the tourism and hospitality industry. Cornell Hospitality Quarterly, 51(2), 171-214.

Lee, J.-S., Back, K.-J., \& Chan, E. S. W. (2015). Quality of work-life and job satisfaction among frontline hotel employees. International Journal of Contemporary Hospitality Management, 27(5), 768-789. doi: doi:10.1108/IJCHM-11-2013-0530

Lockwood, N.R. (2006). Talent Management: Driver for organizationalsuccess.http://www.shrm.org/research/articles/articles/documents/0606rquart pdf.

Lovelock, C., Wirtz, J., Keh, H. T., \& Lu, X. (2005). Service Marketing in Asia: Managing People, Technology, and Strategy. Singapore: Prentice-Hall

MacIntosh, E. W., \& Doherty, A. (2010). The influence of organizational culture on job satisfaction and intention to leave. Sport Management Review, 13, 106-117.doi: 10.1016/j.smr.2009.04.006

Morton, L. (2005). Talent Management Imperatives: Strategies for Successful execution. New York: Conference Board. Research Report R-1345-04-RR

Mwangi, W. (2009). Factors affecting talent management at nation media group. Masters report, Strathmore Business School, Strathmore University, Nairobi.

Nasr, A. (2017). Talent management role in retaining talented employees in five-star hotels. A thesis for the master's degree. The University of Sadat City.

Powell, S., Wood, D. (1999). Is recruitment the time bomb for the industry worldwide? International Journal of Contemporary Hospitality Management, 11(4), 138-139.

Presser, H. (2004). Working in a 24/7 economy: Challenges for American families. PPP psychotherapy. Psychosomatics. Medical psychology, 54(2), 3532.

Smithers, G.L., \& Walker, D.H.T. (2000). The effect of the workplace on motivation and demotivation of construction professionals. Construction Management and Economics, 7(18): 833-841.

Tromp, D. M., \& Blomme, R. J. (2012). The effect of effort expenditure, job control, and workhome arrangements on negative work-home interference in the hospitality industry. International Journal of Hospitality Management, 31, 1213-1221.doi: 10.1016/j.ijhm.2012.02.011

Xin, C., Preece, D., (2008). Is talent management just "old wine in new bottles"? Management Research News, 31(12), 901-911.

William, C., Murray, E., Keith, S., Donnalea, \& Martin, T. (2017). Human resource challenges in Canada's hospitality and tourism industry: Finding innovative solutions. Worldwide Hospitality and Tourism Themes, 9(4), 391-401. 


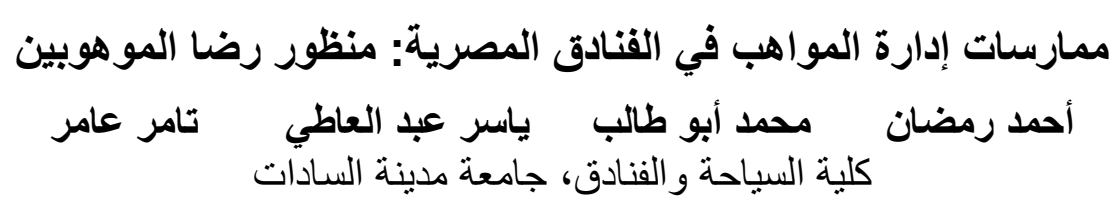

الملخص العربي

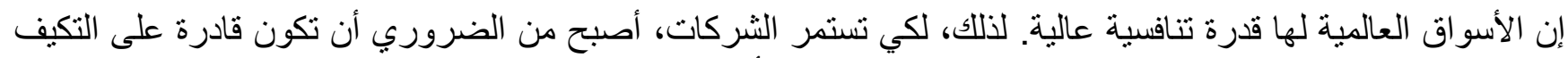

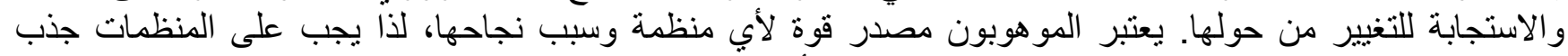

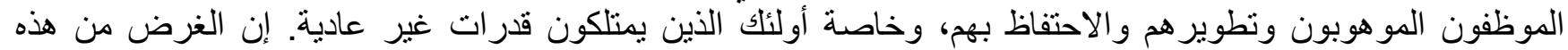

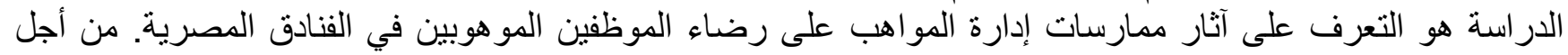

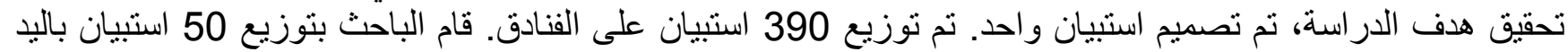

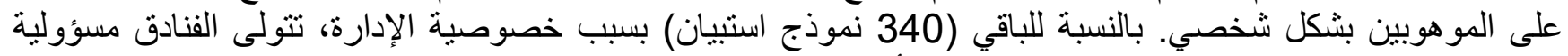

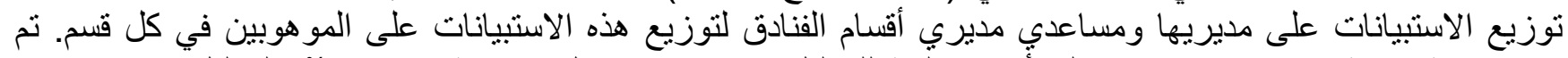

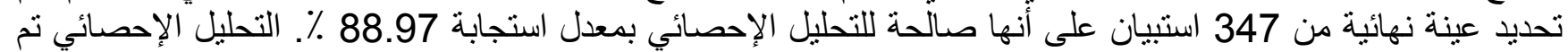

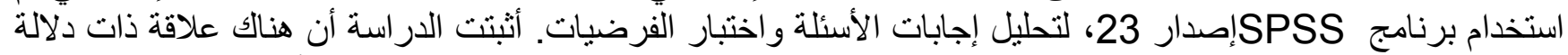

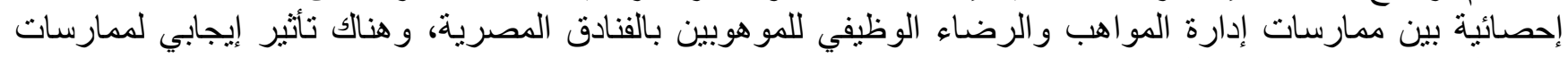

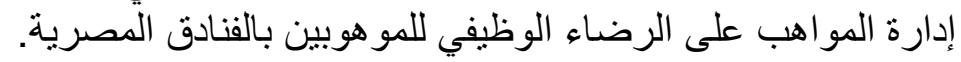
الكلمات الدالة: ممارسات إدارة المواهب، رضاء الرئاء الموظفين، الفنادق. 